\title{
TRANSFORMATION OF THE ORGANIC MATTER OF FOREST AND POST AGROGENIC SOILS OF THE BOREAL ZONE OF RUSSIA
}

\author{
Alexey Vaiman ${ }^{1,2}$, Dmitry Danilov ${ }^{1,2}$, Anatoly Zhigunov ${ }^{1,2}$ \\ ${ }^{1}$ Leningrad Scientific Research Institute of Agriculture 'BELOGORKA', Russia \\ ${ }^{2}$ Saint-Petersburg State Forest Technical University named after S.M. Kirov, Russia \\ 8563706@mail.ru
}

\begin{abstract}
The purpose of the study was to compare forest and postagrogenic soils by parameters such as carbon content in organic matter and total nitrogen to predict the fertility state of lands that are at the stage of restoration of woody vegetation. Areas with similar soil formation conditions were selected on the postagrogenic and forested lands having mature forest stands related with such types of forest: Myrtillosum forest, Oxalidosum and Herbosa-Composita forest, and also areas under the soil complexes of postagrogenic fallow lands. A number of physico-chemical indicators for the soil were assessed according to the methods generally accepted in soil science: the particle size distribution, the bulk density and the thickness of the pedogenic horizons were determined. An analysis of the carbon stocks in organic matter $\left(\mathrm{C}_{\mathrm{org}}\right)$ and nitrogen $\left(\mathrm{N}_{\text {total }}\right)$ in the genetic horizons of the soils of myrtillosum, Oxalidosum and HerbosaComposita forest types shows an increase in the content of organic matter and total nitrogen from Myrtillosum to Herbosa-Composita forest type. A comparative analysis of the physical and agrochemical state of postagrogenic and forest soils showed that, despite the previous anthropogenic impact, the agroland horizon retains a high content of organic matter and total nitrogen. The properties of postagrogenic soils in the studied areas are not deteriorated, and the transformation towards the natural forest soils of the region is not observed, despite the long period of fallowing. Key words: organic matter, nitrogen, postagrogenic lands, Myrtillosum, Oxalidosum and Herbosa-Composita forest types.
\end{abstract}

\section{Introduction}

Soil organic carbon is one of the key elements of the global carbon cycle and can determine the properties of the soil, the content of available nutrient compounds for plants and the overall stability of the entire ecosystem. Soils deposit the most significant long-term volumes of organic carbon, for example, terrestrial ecosystems contain 4. 5 times more carbon from total land biomass and 3 times more than in the atmosphere (Zamolodchikov et al., 2005). The behavior of soil organic carbon is due to climate change and land cover or land use. In a soil ecosystem, organic soil carbon affects the physicochemical processes of the soil and serves as a source of nutrients for plants (Lurie et al., 2010). In recent years, predicting organic carbon stocks in soil has become a key issue due to the potential impact of carbon on climate change. Spatial prediction of organic carbon stocks in the soil has attracted considerable attention due to the large variation of organic matter at all levels.

The distribution of carbon and nitrogen in organic matter over the soil profile depends on many factors, the most important of which are: the mass and composition of incoming litter, its location (in the soil layers, in the litter layer, without contact with the soil), its decomposition intensity, acidity of decomposition products, and chemical properties of soil-forming rock. Recently, organic carbon content in undisturbed forest soils, as well as in soils derived from active agricultural circulation, is studied in many regions of Europe (Stolbovoi, 2002; Lopez de Gerenyu et al., 2009; Tarnocai et al., 2009; Golubeva, 2015; Baeva et al., 2017). The data from these studies suggest that restoration of tree species on postagrogenic lands will lead to a number of changes in the distribution of organic matter over the soil profile (Guzel, 1999; Melekhov, Antonov, \& Lokhov, 2011; Golubeva, 2015; Ryzhova, Erohova, \& Podvezennaja, 2014, Telesnina, 2015; Danilov et al., 2016). These changes associated with fundamentally different structures of functioning of postagrogenic ecosystems at the stages of meadows and forest biocenoses, are inevitable (Lopez de Gerenyu et al., 2009; Martens, Reedy, \& Lewis, 2004; Poeplau et al., 2005; Zamolodchikov et al., 2005; Pan et al., 2011). Restoration of woody vegetation on postagrogenic lands will be accompanied by changes in the distribution of organic matter over the soil profile. These changes related to fundamentally different structures of functioning of meadow and woody biocenoses are inevitable. Meadow biocenoses have a short closed organic matter cycle, much of which is in the root fraction. In forest biocenoses, most of the synthesized substance goes to the growth of wood pulp of trunks and roots of trees, where organic matter would be located for many years and decades. In forest stands, most of the dead plant residues come at the soil surface in the form of leaf litter and woody debris, where they decompose, and their decomposition products are washed away with sediments and re-enter the soil. Forest detritus and woody debris decompose even much more slowly compared to the meadow one. Forest litter degradation takes place with the release of acidic decomposition products which, when released into the soil, affect the mineral part of the soil; that is manifested in the formation of a podzolic horizon in the soil profile. 
In the meadow biocenoses, most of the intake of dead plant debris falls on the roots, and their decomposition takes place in the soil at the place of their formation. Meadow biocenoses differ from forest ones not only by a large mass of litter, but also by a high dispersion of plant residues in the top layer of soil, high nitrogen content, which contributes to their intensive decomposition and accelerated humification.

The changes will take place over a long period of time, amounting up to several decades. The first signs of changes will appear only after the tree crowns are closed, that is, with the beginning of formation of the forest phytocenosis. It is believed that the removal of arable land from crop rotation leads to an increase in the reserves of organic carbon in the soil due to the increasing amount of organic material introduced into it. But at the same time, it is necessary to take into account the level of agrotechnical measures carried out earlier for the studied soils. So, when the forest becomes overgrown with well-cultivated sod-podzolic soils, their humus state worsens (Litvinovich, Pavlova, $\&$ Chernov, 2002). On the other hand, there are studies that show the behavior of humus state indicators of postagrogenic soils in the course of natural forest regrowth using the example of soil time series derived from different crop rotation systems; they indicate an increase in the content of humus in the course of colonization of arable lands by vegetation and, on the contrary, some decrease in early stages of succession when a haying is overgrown (Telesnina, 2015). A comparative analysis of the carbon stocks behavior during postagrogenic succession in different regions of the European territory of Russia suggests that the same pattern is observed with the overgrowing of arable land with forest at different quantitative levels (Lurie et al., 2010). At the first stages of succession, a decrease in soil carbon stocks is noted, with its subsequent increase at the following stages ranging from $30-80$ to $150-170$ years.

Estimates of carbon stock changes with a change in the nature of land use are of great interest: their greatest increase in soil up to $53 \%$ occurs with the natural regeneration of forest on former arable land. When forest plantations are created on arable land, carbon stocks increase by $18 \%$, and they decrease on pastures by $10 \%$ (Guo \& Gifford, 2002). In temperate climate conditions, the increase in carbon stocks in the soil makes $16 \pm 7 \%$ during the first 20 years of forest formation in the former arable land (Poeplau, Don, Vesterdal, Leifeld, et al., 2005). After 100 years, the carbon content increases by $83 \pm 39 \%$ in the upper horizon with a capacity of $28 \pm 13 \mathrm{~cm}$, and taking into account litter - by $116 \pm 54 \%$. Many researchers recognize the leading role of organic matter in the formation of soil fertility (Fernandez-Martinez et al., 2014; Romanovskaya, 2006; Hooker, 2013). The main limiting factor in plant growth is often the content of available nitrogen in the soil. Its main part in the soil (up to 90\%) is found in various specific humic substances, and only a small part of it is found in inhumified organic and mineral compounds.

Soil cultivation causes a diverse and profound effect on the biological, chemical, and physical properties of the soil, which leads to a change in the entire soil-forming process as a whole. Sod-podzolic soils lose their original features and acquire new ones. A powerful arable horizon is created there increasing the content of carbon, nitrogen and other elements of mineral nutrition. An increase in the carbon content is accompanied by a redistribution of the group composition of humic substances, an increase in the group of humic and a decrease in fulvic acids. Organic matter becomes less mobile, and more resistant to leaching and destruction. Along with a change in organic matter, an increase in the total nitrogen content is observed, but the amount of its hydrolysable fractions decreases (Fernandez-Martinez et al., 2014).

Boreal forests deposit carbon not only in woody biomass, but also in woody detritus, humus and in soil.

Forests growing on fertile soils with an adequate supply of nutrients can deposit about $30 \%$ of carbon for a long time; they absorb carbon during photosynthesis (Fernandez-Martinez et al., 2014). In contrast, forests growing on nutrient poor soils can deposit only $6 \%$ of carbon, since the rest of the volume is returned to the atmosphere.

Despite the availability of data on carbon stocks in the soils of various plant ecosystems, there is no complete picture of this issue. Therefore, the aim of the study was to compare forest and postagrogenic soils for such parameters as the carbon content of organic matter and total nitrogen, and to predict the fertility of land derived from active economic turnover.

\section{Materials and Methods}

Areas with similar soil formation conditions were selected on postagrogenic and forest lands within the limits of carbonate rocks in the south-west of the Leningrad Region in two administrative districts of Gatchina (30.2919086; 59.3695495999) and Volosovsky (59.370409; 29. 497581). We studied the content of organic matter and nitrogen in the profile of forest soils on 3 sites, under mature forest stands and on agricultural land derived from active agricultural use more than 35 years ago. For the study, spruce stands were selected as the most typical for the region of study. Indicators of forest stand on Herbosa-Composita forest types were at the age of 90 years, wood stock $400 \mathrm{~m}^{3} \mathrm{ha}^{-1}$, average height $30 \mathrm{~m}$, average diameter $36 \mathrm{~cm}$. Indicators of forest stand on Oxalidosum forest types were at the age of 90 years, wood stock $350 \mathrm{~m}^{3} \mathrm{ha}^{-1}$, average height $26-28 \mathrm{~m}$, 
average diameter $28-30 \mathrm{~cm}$. Indicators of forest stand on Myrtillosum forest types were at the age of 90 years, wood stock $320 \mathrm{~m}^{3} \mathrm{ha}^{-1}$, average height 26 $\mathrm{m}$, average diameter $28 \mathrm{~cm}$. Natural regeneration of woody and shrubby vegetation in the areas of fallow lands is represented by birch, aspen, alder, and willow shrub. The average height of hardwood is 2 to 4 meters. The distribution of woody vegetation is uneven. Wood stock in the studied areas is from 30 to $40 \mathrm{~m}^{3} \mathrm{ha}^{-1}$. The research methodology is based on standard methods of soil science (Bankin et al., 2005). Soil pits and small trenches were laid in the most characteristic places of the surveyed area at each experimental site, excluding areas with non-typical microrelief elements and signs of soil disturbance. A number of soil physicochemical indicators were evaluated using generally accepted methods of soil science: the particle size distribution, the density of composition and the thickness of pedogenic horizons were determined. The density of composition of all horizons was estimated according to Kaczynski; carbon determination was carried out by dry ashing of total nitrogen according to Kjeldahl, $\mathrm{pH}$ of the salt extract - by the potentiometric method. Based on the data obtained, a comparative analysis was carried out.

\section{Results and Discussion}

The comparative analysis of the carbon stocks in organic matter $\left(\mathrm{C}_{\mathrm{org}}\right)$ and nitrogen $\left(\mathrm{N}_{\text {total }}\right)$ in the genetic horizons of the soils of the Myrtillosum, Oxalidosum and Herbosa-composita forest types shows an increase in the content of organic matter and total nitrogen from the Myrtillus to Herbosa-composita forest and grass type (Tables 1-3). An integral indicator of soil fertility, which determines the productivity of the forest stand, is the $\mathrm{C}: \mathrm{N}$ ratio in the humus horizon of the soil. In Herbosa-composita forest types, forest stands of productivity class I are mainly represented; in Myrtillus forest types, the productivity decreases to class II. At the same time, an increase in $\mathrm{C}: \mathrm{N}$ ratio by organic matter in the humus horizons of the soil from $8-12$ in Herbosa-composita types of forests to C:N about 17 - 18 in Myrtillus forest types and mountain Oxalidosum forest types is traced.

An analysis of the agrochemical indicators of highly productive forest stands shows that there is no clear correlation between the productivity of mature forest stands and acid-base indicators of the soil (Tables 1-3). Soil acidity in Myrtillus forest and Oxalidosum forest types increases down the soil profile. The lowest $\mathrm{pH}$ value was observed in the upper horizon, in the soil profile of a Myrtillus forest type, and it was equal to 3.7. In Herbosa-composita forest types, the $\mathrm{pH}$ is close to neutral values throughout the soil profile, since these soils are formed on a limestone moraine.

Low soil acidity in Myrtillus forest and oxalidosum forest types is associated with the impact of coniferous

\section{The carbon stock of organic matter $(C)$ and total nitrogen $(N)$ in the genetic} horizons of forest soil Myrtillus, $\mathrm{t} \mathrm{ha}^{-1}$

Table 1

\begin{tabular}{|c|c|c|c|c|c|c|c|c|}
\hline \multirow{2}{*}{$\begin{array}{l}\text { Soil-forming rock } \\
\text { Soil }\end{array}$} & \multirow{2}{*}{\multicolumn{2}{|c|}{$\begin{array}{l}\text { Horizon } \\
\text { Depth, cm }\end{array}$}} & \multirow{3}{*}{$\begin{array}{c}\begin{array}{c}\text { Volume weight, } \\
\mathrm{g} \mathrm{cm}^{-3}\end{array} \\
0.17\end{array}$} & \multirow{3}{*}{$\frac{\mathrm{pH}_{(\mathrm{KCl})}}{3.7}$} & \multicolumn{4}{|c|}{ Soil organic matter } \\
\hline & & & & & $\mathrm{C}_{\mathrm{org}}, \%$ & $\begin{array}{c}\mathrm{C}_{\text {org }} \\
\mathrm{t} \mathrm{ha}^{-1}\end{array}$ & $\mathrm{C}: \mathrm{N}$ & $\begin{array}{c}\mathrm{N}_{\text {total }}, \mathrm{t} \\
\mathrm{ha}^{-1}\end{array}$ \\
\hline \multirow{4}{*}{$\begin{array}{l}\text { Moraine non-carbonate } \\
\text { loam, } \\
\text { Moderate and coarse } \\
\text { humus podzolic }\end{array}$} & $\mathrm{A}_{0}$ & 4.2 & & & 30 & 21.4 & 30.0 & 0.71 \\
\hline & $\mathrm{A}_{1}$ & $0-10$ & 0.63 & 3.6 & 3.05 & 19.22 & 18.2 & 1.06 \\
\hline & $\mathrm{A}_{2}$ & $10-32$ & 1.32 & 3.7 & 0.36 & 10.45 & 9.0 & 1.16 \\
\hline & $\mathrm{A}_{2} \mathrm{~B}$ & $32-46$ & 1.56 & 4.3 & 0.30 & 6.55 & 7.5 & 0.87 \\
\hline
\end{tabular}

The carbon stock of organic matter $(C)$ and total nitrogen $(N)$ in the genetic horizons

Table 2 of forest soil Oxalis, $\mathbf{t ~ h a}$ - $^{-1}$

\begin{tabular}{|c|c|c|c|c|c|c|c|c|}
\hline \multirow{2}{*}{$\begin{array}{l}\text { Soil-forming rock } \\
\text { Soil }\end{array}$} & \multirow{2}{*}{\multicolumn{2}{|c|}{$\begin{array}{l}\text { Horizon } \\
\text { Depth, cm }\end{array}$}} & \multirow{3}{*}{$\begin{array}{l}\begin{array}{c}\text { Volume weight, } \\
\mathrm{g} \mathrm{cm}^{-3}\end{array} \\
0.14\end{array}$} & \multirow{3}{*}{$\begin{array}{c}\mathrm{pH}_{(\mathrm{KCl})} \\
3.8\end{array}$} & \multicolumn{4}{|c|}{ Soil organic matter } \\
\hline & & & & & $\mathrm{C}_{\text {org, }} \%$ & $\begin{array}{l}\mathrm{C}_{\text {org }} \\
\mathrm{t} \mathrm{ha}^{-1}\end{array}$ & $\mathrm{C}: \mathrm{N}$ & $\begin{array}{c}\mathrm{N}_{\text {total }} \mathrm{t} \\
\text { ha }^{-1}\end{array}$ \\
\hline \multirow{4}{*}{$\begin{array}{l}\text { Moraine non-carbonate } \\
\text { loam } \\
\text { Moderate humus podzolic }\end{array}$} & $\mathrm{A}_{0}$ & $0-5$ & & & 28 & 12.2 & 23.0 & 0.53 \\
\hline & $\mathrm{A}_{1}$ & $5-15$ & 0.72 & 3.8 & 4.55 & 32.76 & 16.8 & 1.95 \\
\hline & $\mathrm{A}_{2}$ & $15-27$ & 1.44 & 4.1 & 0.60 & 10.37 & 12.0 & 0.86 \\
\hline & $\mathrm{A}_{2} \mathrm{~B}$ & $27-49$ & 1.51 & 4.4 & 0.48 & 15.95 & 9.6 & 1.66 \\
\hline
\end{tabular}


The carbon stock of organic matter $(C)$ and total nitrogen $(N)$ in the genetic horizons of forest soil Herbosa-composita, $\mathrm{t}$ ha $^{-1}$

\begin{tabular}{|c|c|c|c|c|c|c|c|c|}
\hline \multirow{2}{*}{$\begin{array}{l}\text { Soil-forming rock } \\
\text { Soil }\end{array}$} & \multirow{2}{*}{\multicolumn{2}{|c|}{$\begin{array}{l}\text { Horizon } \\
\text { Depth, cm }\end{array}$}} & \multirow{3}{*}{$\begin{array}{c}\begin{array}{c}\text { Volume } \\
\text { weight, } \mathrm{g} \mathrm{cm}^{-3}\end{array} \\
0.11\end{array}$} & \multirow{3}{*}{$\frac{\mathrm{pH}_{(\mathrm{KCl})}}{6.8}$} & \multicolumn{4}{|c|}{ Soil organic matter } \\
\hline & & & & & \multirow{2}{*}{$\frac{\mathrm{C}_{\mathrm{org}} \%}{23}$} & \multirow{2}{*}{$\begin{array}{c}\begin{array}{c}\mathrm{C}_{\text {org }} \\
\mathrm{t} \mathrm{ha}^{-1}\end{array} \\
3.8\end{array}$} & \multirow{2}{*}{$\begin{array}{l}\mathrm{C}: \mathrm{N} \\
21.0\end{array}$} & \multirow{2}{*}{$\begin{array}{c}\begin{array}{c}\mathrm{N}_{\text {total }}, \mathrm{t} \\
\mathrm{ha}^{-1}\end{array} \\
0.18\end{array}$} \\
\hline \multirow{5}{*}{$\begin{array}{l}\text { Carbonate loam, } \\
\text { Leached soil }\end{array}$} & $\mathrm{A}_{0}$ & $0-1$ & & & & & & \\
\hline & \multirow{2}{*}{$\mathrm{A}_{1}$} & $1-10$ & 0.9 & 6.8 & 3.8 & 34.2 & 12.0 & 2.85 \\
\hline & & $10-22$ & 1.1 & 6.8 & 2.9 & 31.9 & 8.5 & 3.75 \\
\hline & $\mathrm{A}_{2} \mathrm{~B}$ & $22-32$ & 1.35 & 6.7 & 1.2 & 13.5 & 7.9 & 1.7 \\
\hline & B & $32-60$ & 1.55 & 6.8 & 0.86 & 37.3 & 7.5 & 5.0 \\
\hline
\end{tabular}

litter on carbon-free soil-forming rocks, which favors actively the development of fungal flora involved in the decomposition of forest litter and mycotrophic feeding of tree species (Fedorchuk, Neshataev, \& Kuznetsova, 2005). It is also worth noting the decrease in the content of organic carbon from the humus horizon to the podzolized ones: in the Herbosa-composita types of forest - by 2.8, in Oxalidosum - by 7.6, in Myrtillus forests - by 8.5 times. At the same time, there is a decrease with the depth of the $\mathrm{C}: \mathrm{N}$ ratio profile:

- in sod-carbonate soil from 10 (in a layer of $0-20$ $\mathrm{cm}$ ) to 7.5 (in a layer of $32-60 \mathrm{~cm}$ );

- in sod-podzolic from 16.8 (in a layer of $5-15$ $\mathrm{cm})$ to 9.6 in a layer of $27-49$.

In the arable horizon of soils that are actively used in agricultural crop rotation in the area under study, the content of $\mathrm{C}_{\text {org }}$ ranges from $11.1 \mathrm{tha}^{-1}$ to $33.3 \mathrm{t} \mathrm{ha}^{-1}$ (Boytsova \& Regia, 2014).

As arable land overgrown with grass and shrub species of plants occurs, a certain increase of $\mathrm{C}_{\text {org }}$ content in upper horizon of postagrogenic soil is observed (Table 4). After removal of arable soil from agricultural use, weed vegetation begins to develop on them, which over time should be replaced by natural phytocenosis (Golubeva, 2015; Zamolodchikov et al., 2005; Lurie et al., 2010; Telesnina, 2015). At the initial stages of overgrowing, the intake of a greater amount of fresh organic material in the form of plant and root litter increases as there is no alienation of biomass in the form of crop taken. All those contribute to the accumulation of carbon in the former arable horizon.

At present, the stage of overgrowth with trees and shrubs such as birches, aspens, and willows begins in the postagrogenic sites under study. Renewal is curtain in nature or occurs on micro depressions of the former fissures. The content of organic matter in the arable horizon of these areas of postagrogenic lands is at the level of mountain sorrel forest type, and the $\mathrm{pH}$ value on these soils does not have a wide variation in contrast to the forest soils of those forest types. The content of total nitrogen in these soils is high: from 5 to $7.4 \mathrm{t} \mathrm{ha}^{-1}$ at the level of the oak-grass type of forest.

Table 4

Characteristics of soil conditions of the surveyed land no longer used for agricultural purposes (prescription deposits of 30-35 years)

\begin{tabular}{|c|c|c|c|c|c|c|c|c|}
\hline \multirow[b]{2}{*}{ Site\#. } & \multirow{2}{*}{$\begin{array}{l}\text { Soil-forming rock } \\
\text { Soil }\end{array}$} & \multirow{2}{*}{$\begin{array}{l}\text { Horizon, } \\
\text { A arable, } \\
50 \mathrm{~cm}\end{array}$} & \multirow{2}{*}{$\begin{array}{c}\text { Volume } \\
\text { weight, } \mathrm{g} \\
\mathrm{cm}^{-3}\end{array}$} & \multirow[b]{2}{*}{$\mathrm{pH}_{(\mathrm{KCl})}$} & \multicolumn{4}{|c|}{ Soil organic matter } \\
\hline & & & & & humus, $\%$ & $\begin{array}{c}\mathrm{C}_{\mathrm{org}^{-1}}, \mathrm{t} \\
\mathrm{ha}^{-1}\end{array}$ & $\begin{array}{c}\mathrm{N}_{\text {total }}, \mathrm{t} \\
\text { ha }^{-1}\end{array}$ & $\mathrm{C}: \mathrm{N}$ \\
\hline \multirow[t]{2}{*}{1} & \multirow{2}{*}{$\begin{array}{c}\text { Sod low-podzolic, gleied and } \\
\text { loamy on red-brown sandy } \\
\text { loam moraine }\end{array}$} & 35.0 & \multirow{2}{*}{1.14} & 5.9 & 2.0 & 56.8 & 4.9 & 12.0 \\
\hline & & 15.0 & & 5.9 & 1.0 & 11.3 & 2.5 & 5.0 \\
\hline \multirow[t]{2}{*}{2} & \multirow{2}{*}{$\begin{array}{c}\text { Sod-podzolic sandy loam } \\
\text { on the moraine deposits of } \\
\text { Devonian rocks }\end{array}$} & 30 & \multirow[t]{2}{*}{1.27} & 5.3 & 2.7 & 54.0 & 5.1 & 10.6 \\
\hline & & 20 & & 4.9 & 1.4 & 21.1 & 1.9 & 11.1 \\
\hline \multirow[t]{2}{*}{3} & \multirow{2}{*}{$\begin{array}{c}\text { Sod-podzolic gleyic light } \\
\text { loamy on moraine deposits of } \\
\text { Devonian rocks }\end{array}$} & 25 & \multirow[t]{2}{*}{1.13} & 5.2 & 1.89 & 35.6 & 3.1 & 11.5 \\
\hline & & 25 & & 5.2 & 1 & 18,8 & 1.6 & 11.8 \\
\hline \multirow[t]{2}{*}{4} & \multirow{2}{*}{$\begin{array}{l}\text { Sod-podzolic, light loamy on } \\
\text { moraine deposits of Devonian } \\
\text { rocks }\end{array}$} & 30 & \multirow{2}{*}{1.14} & 5.2 & 1.89 & 37.5 & 3.2 & 11.7 \\
\hline & & 20 & & 5 & 1 & 14.5 & 1.4 & 10.4 \\
\hline
\end{tabular}


The $\mathrm{C}: \mathrm{N}$ ratio characterizing the enrichment of humus with nitrogen, for most agroland horizons of those soils is equal to $8-10$, which corresponds to a high and moderate degree of availability of this element. A very high ratio $(18-20)$ is characteristic of nitrogen-poor coarse-humus horizons of forest soils (Fedorchuk et al., 2005). By the content of $\mathrm{C}_{\text {org }}$ and $\mathrm{N}_{\text {total }}$ in the upper soil horizon, the following descending series is formed:

Herbosa-composita forest type $>$ fallow land $>$ Oxalidosum forest type > Myrtillus forest type > arable land.

Forest soils are characterized by a high level of variation of the $\mathrm{C}: \mathrm{N}$ ratio along the profile. In the upper layer of postagrogenic soils, this ratio usually slightly varies and is $11-12$, which confirms their high potential fertility.

No less important indicator reflecting soil fertility is the bulk density. $1.1-1.2 \mathrm{~g} \mathrm{~cm}^{-3}$ are suggested as the optimum values for loamy soils (Litvinovich, Pavlova, \& Chernov, 2002; Golubeva, 2014). For arable horizons that are actively used in soil rotation, this figure ranges from 0.8 to $1.1 \mathrm{~g} \mathrm{~cm}^{-3}$. For forest soils, this indicator has a small value of $0.6-0.7 \mathrm{~g}$ $\mathrm{cm}^{-3}$ in the upper part of the profile (to a depth of $10-$ $15 \mathrm{~cm}$ ), and then begins to increase to $1.55 \mathrm{~g} \mathrm{~cm}^{-3}$ (at a depth of $30-40 \mathrm{~cm}$ ). For fallow postagrogenic soils, the density of the arable layer varies from 1.11 to $1.4 \mathrm{~g}$ $\mathrm{cm}^{-3}$, which indicates a tendency to compaction.

\section{Conclusions}

1. Summarizing the results for the comparative analysis of the physical and agrochemical state of postagrogenic and forest soils it can be noted that, despite the previous anthropogenic impact, the agroland horizons retain a high content of organic matter and total nitrogen.

2. The postagrogenic soil properties in the studied areas do not deteriorate and the transformation towards the natural forest soils of the region is not observed, despite the long period of fallowing (over 35 years). The tree vegetation on these lands is in the stage of formation and the stage of closure of the crowns has not come.

3. The total nitrogen content in the postagrogenic soils of the surveyed areas exceeds the indicators for the soils of the most productive forest types in the region under study. The carbon to nitrogen ratio in postagrogenic soils over the entire soil profile shows a higher fertility than in forest soils, where $\mathrm{C}: \mathrm{N}$ is optimal only for the part of horizon $\mathrm{A}_{1}$.

4. In forest soils, the largest supply of organic matter of carbon is concentrated in the litter; in the postagrogenic soils, it is concentrated in the upper layer of the former arable horizon. Unlike the forest soils, there is a slight increase in the compaction of the soil profile here.

5. With the overgrowth of developed low-carbon postagrogenic soils, its reserves will increase. The recovery time depends on the granulometric composition of the soil and on the difference in carbon reserves between the soils of the former arable land and the compared soils of the most productive forest types.

\section{References}

1. Baeva, Yu.I., Kurganova, I.N., Lopez de Guerenu, V.O., \& Telesnina, V.M. (2017). Сравнительная оценка содержания углерода в постагрогенных почвах различных природно-климатических зон (Comparator assessment of carbon content in postagrogenic soils at different native climatic zones). PEMME. XXVIII, (2). 29-39. (in Russian)

2. Bankin, M.P., Bankina, T.A., \& Korobeynikova, L.P. (2005). Физико-химические методы в агрохимии и биологии почв (Physical and chemical methods in Agrochemistry and soil biology). St. Petersburg: Publishing house of St. Petersburg state University, 177 p. (in Russian)

3. Boytsova, L.V., \& Regia, E.Y. (2014). Определение содержания общего органического углерода в дерново-подзолистой почве с помощью методов окисления и учета выделившегося углекислого газа (Determination of total organic carbon in sod-podzolic soil using oxidation and accounting methods released carbon dioxide). Agrophysics. Physics, Biophysics and ecology. 3(15), 20-27. (in Russian)

4. Danilov, D.A., Zhigunov, A.V., Krasnovidov, A.N., Ryabinin, B.N., Neverovsky, V.Yu., Shestakova, T.A., Shestakov, V.I., \& Enders, O.O. (2016). Cultivation of wood plantations on postagrogenic lands. SPb.: Publishing house of Polytechnical Institute. UNTA, $130 \mathrm{p}$.

5. Fedorchuk, V.N., Neshataev, V.Yu., \& Kuznetsova, M.L. (2005). Лесные экосистемы северо-западных районов России: типология, динамика, хозяйственные особенности (Forest ecosystems of the NorthWestern regions of Russia: typology, dynamics, economic features). SPb. Publ. SpbGLTa, 382 p. (in Russian)

6. Fernandez-Martinez, M., Vicca, S., Janssens, I.A., Sardans, J., Luyssaert, S., Campioli, M., Chapin, F.S., Ciais, P., Malhi, Y., Obersteiner, M., Papale, D., Piao, S. L., Reichstein, M., Rodà, F., \& Peñuelas, J. (2014). 
Nutrient availability as the key regulator of global forest carbon balance. Nature Climate Change, 4 (6), 471-476.

7. Golubeva, L.V. (2015). Лесоводственно-экологическая трансформация постагрогенных земель на карбонатных отложениях в подзоне средней тайги Архангельской области (Forest-ecological transformation of post-agrogenic lands on carbonate sediments in the sub-zone of the middle taiga of the Arkhangelsk region). The dissertation of the candidate of agricultural sciences. Arkhangelsk: Northern (Arctic) Federal University named after M.V. Lomonosov, 160 p. (in Russian)

8. Guo, L.B., \& Gifford, R.M. (2002). Soil carbon stocks and land use change: a meta-analysis. Global Change Biology. 8, 4, 345-360.

9. Guzel, N.I. (1999). Изменения почвенного покрова при зарастании бывших сельскохозяйственных земель на Карельском перешейке (Changes of soil cover in the overgrowing of former agriculturalagricultural land on the Karelian Isthmus). Materials for the study Russian soil. 1 (28), (in Russian)

10. Hooker, T.D., \& Compton, J.E. (2003). Forest ecosystem carbon and nitrogen accumulation during the first century after agricultural abandonment. Ecol. Appl., 13, (2), 299-313.

11. Litvinovich, A.V., Pavlova, O.Yu., \& Chernov, D.V. (2002). Изменение гумусового состояния дерновоподзолистой почвы при прекращении антропогенного воздействия (Change of humus co-standing sodpodzolic soil at the termination of anthropogenic impact). Report of the Russian Academy of agricultural Sciences.6. 26-28. (in Russian)

12. Lopez de Gerenyu, V.O., Kurganova, I.N., Ermolaev, A.M., ... Kuzyakov, Y. (2009). Изменение пулов органического углерода при самовосстановлении пахотных черноземов (Changes in organic carbon pools during self-recovery of arable black soil). Agrochemistry. 5. 5-12. (in Russian)

13. Lurie, D.I., Goryachkin, S.V., Karavaeva, N.A., Denisenko, E.A., \& Nefedova, T.G. (2010). Динамика сельскохозяйственных земель России в XX веке постагрогенное восстановление растительности и почв (Dynamics of agricultural land in Russia in the XX century postagrogenic-formation of vegetation and soils). M.: GEOS, 416 p. (in Russian)

14. Martens, D.A., Reedy, T.E., \& Lewis, D.T. (2004). Soil organic carbon content and composition of 130 year crop, pasture and forest land use managements. Global Change Biology, 10, 65-78.

15. Melekhov, V.I., Antonov, A.M., \& Lokhov, D.V. (2011). Лесоводственный потенциал неиспользуемых сельскохозяйственных угодий (Forestry potential of unused agricultural land). Bulletin of the Pomeranian University. 3. 62-66. (in Russian)

16. Pan, Y., Birdsey, R., Fang, J., Houghton, R., Kauppi, P.E., Kurz, W.A., \& Phillips, O.L. (2011). A Large and Persistent Carbon Sink in the World's Forests. Science, 333, (6045), Published Online 14 July, 2011.

17. Poeplau, C., Don, A., Vesterdal, L., Leifeld, J., Van Wesemael, B.A.S., Schumacher, J., \& Gensior, A. (2011). Temporal dynamics of soil organic carbon after land-use change in the temperate zone - carbon response functions as a model approach. Glob. Change Biol, 17, 2415-2427.

18. Romanovskaya, A.A. (2006). Organic carbon in long-fallow lands of Russia. Eurasian Soil Science. 39, (1), 44-52.

19. Ryzhova, I.M., Erohova, A.A., \& Podvezennaja, M.A. (2014). Динамика и структура запасов углерода в постагрогенных экосистемах южной тайги (Dynamics and structure carbon in postagrogenic ecosystems of the southern taiga). Soil science. 12, 1426-1435. (in Russian)

20. Stolbovoi, V. (2002). Carbon in Russian soils. Climatic Change, 55, 131-156.

21. Tarnocai, C., Canadell, J.G., Schuur, E.A.G., Kuhry, P., Mazhitova, G., \& Zimov, S. (2009). Soil organic carbon pools in then or then circumpolar permafrost region. Global Bio-geochemical Cycles, No. 23. GB2023.

22. Telesnina, V.M. (2015). Постагрогенная динамика растительности и свойств почвы в ходе демутационной сукцессии в южной тайге (Postagrogenic dynamics of vegetation and soil properties in during the demutational succession in the southern taiga). Forestry. 4, 293-306. (in Russian)

23. Zamolodchikov, D.G., Korovin, G.N., Utkin, A.I., Chestnyh, O.V., \& Songen, В. (2005). Углерод в лесном фонде и сельскохозяйственных угодьях России (Carbon in forest background and agricultural lands of Russia). M.: KMC, 212 p. (in Russian) 